\title{
Coupled Electro-Thermal Analysis of the Micro Flow Sensor with Control Circuit using SPICE
}

\author{
Shoji Kamiunten Member (Tokyo University of Science and Yamatake Corp., kamiunten-shoji@jp.yamatake.com) \\ Hidetomo Nagayo Non-member (Tokyo University of Science) \\ Masahiro Motosuke Non-member (Tokyo University of Science) \\ Shinji HonamiＮon-member (Tokyo University of Science, honamis@rs.kagu.tus.ac.jp)
}

Keywords : flow sensor, MEMS, modeling, SPICE, equivalent thermal circuit, heat transfer

This paper reports an electro-thermal analysis of two-element Micro Flow Sensor (MFS) as shown in Fig.1. MFS is a thermal type fluid mass flow sensor fabricated by utilizing MEMS (Micro Electro Mechanical Systems) technology. Since MFS has outstanding features such as high sensitivity and rapid response, their applications are increasing with each decade. The measurement principle was investigated for two-element MFS. The output is defined as a temperature difference between upstream and downstream part of electrically connected two heating-sensing elements. The two elements were controlled at constant temperature which is higher than the ambient one by the circuit (see Fig.2). The two-heater MFS, the thermal fluid flow around MFS and the electric circuit were modeled together using a commercial general-purpose circuit simulator based on SPICE (Simulation Program with Integrated Circuit Emphasis). The model has a partial three-dimensional lumped thermal network model involved in a two-dimensional one (see Fig.3). Two-dimensional laminar Poiseuille channel flow was assumed as the flow field in the model, and the forced convective heat transfer was calculated by energy balance at each node in the fluid flow.

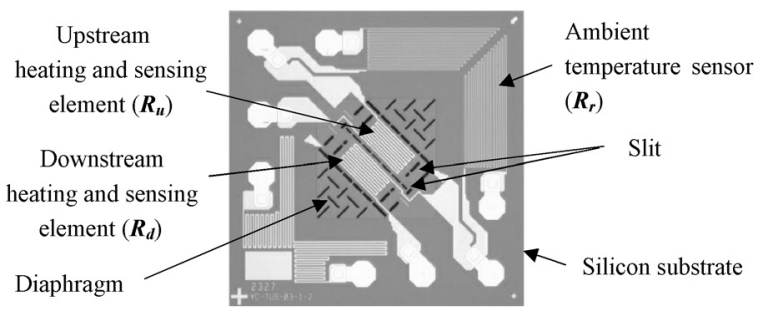

Fig. 1. Top view of the two-element MFS

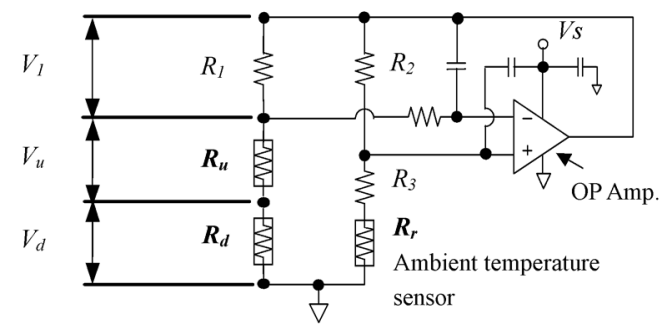

$\boldsymbol{R}_{\boldsymbol{u}}$ : Upstream heating and sensing element

$\boldsymbol{R}_{\boldsymbol{d}}$ : Downstream heating and sensing element

Fig. 2. Control circuit of the two-element MFS
The tendency on the sensor characteristics was in good agreement between the simulation and experiment as shown in Fig.4, and the complex thermal and electrical behaviors of the MFS were predicted precisely. The calculated temperature distributions around MFS is shown in Fig.5. This simulation can be used as a powerful tool for developing sensor applications and optimization of the sensor design.

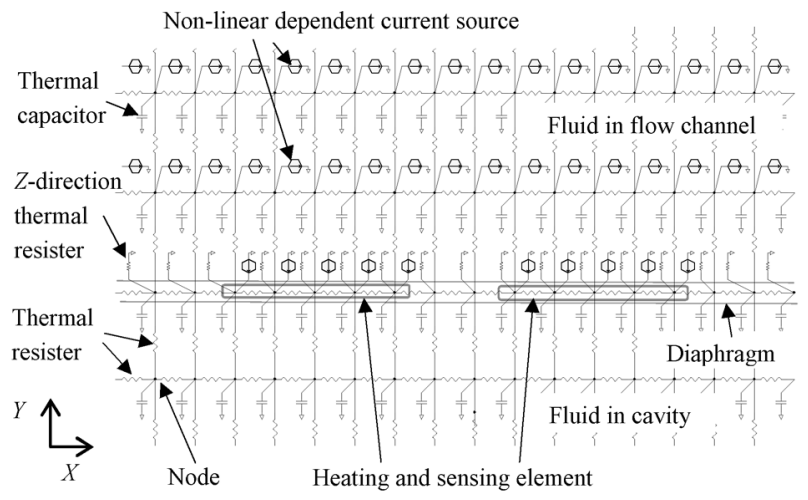

Fig. 3. Part of equivalent thermal circuit on Simulator

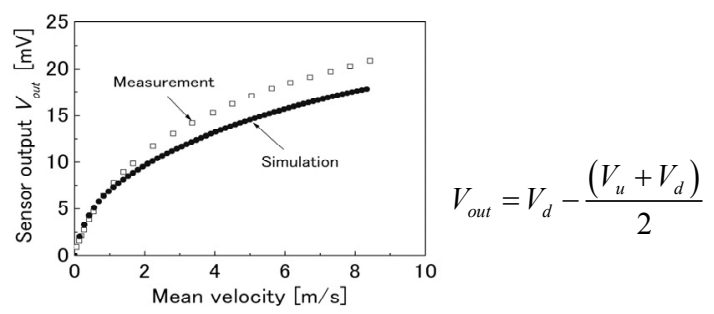

Fig. 4. Characteristics of sensor output $\left(V_{\text {out }}\right)$

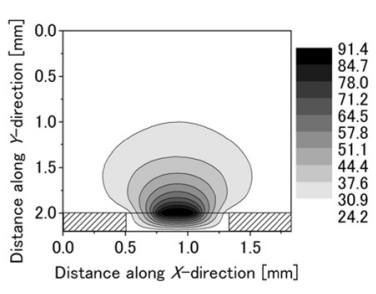

(a) $U_{m}=0[\mathrm{~m} / \mathrm{s}]$

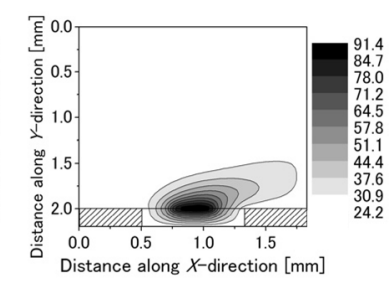

(b) $U_{m}=0.5[\mathrm{~m} / \mathrm{s}]$
Fig. 5. Temperature distribution around the twoelement MFS 


\title{
マイクロフローセンサと制御回路の SPICE を用いた 電気-熱 連成解析
}

\author{
正 員 上運天昭司 $* * *$ 非会員 永代 秀友* \\ 非会員 元祐 昌廣* 非会員 本阿弥眞治*
}

\section{Coupled Electro-Thermal Analysis of the Micro Flow Sensor with Control Circuit using SPICE Shoji Kamiunten*,**, Member, Hidetomo Nagayo*, Non-member, Masahiro Motosuke*, Non-member, Shinji Honami*, Non-member}

This paper reports an electro-thermal analysis of two-element Micro Flow Sensor (MFS). The measurement principle is based on temperature difference between upstream and downstream part of electrically connected heating-sensing elements. The two-heater MFS, the thermal fluid flow around MFS and the electric circuit were modeled together using a commercial general-purpose circuit simulator based on SPICE (Simulation Program with Integrated Circuit Emphasis). The model has a partial three-dimensional lumped thermal network model involved in a two-dimensional one. Two-dimensional laminar Poiseuille channel flow was assumed as the flow field in the model, and the forced convective heat transfer was calculated by energy balance at each node in the fluid flow. The tendency on the sensor characteristics was in good agreement between the simulation and experiment.

キーワード：フローセンサ，MEMS，モデル化，SPICE，熱等価回路，伝熱

Keywords : flow sensor, MEMS, modeling, SPICE, equivalent thermal circuit, heat transfer

\section{1. はじめに}

現在，様々な種類の流量計が使用されているが，そのほ とんどが長い歴史を持つものであり，新しい種類の流量計 が登場し市場に定着することは少ない。そういう中で, MEMS (Micro Electro Mechanical Systems) 技術によって製作 されたマイクロフローセンサ（以下，MFS）を用いた気体 用流量計は，フィールドでの 10 年以上の実績を経て，燃焼 制御，ガス供給管理，医療，省エネ，燃料電池，など様々 な分野でその有用性が確認され地位を確立しつつある(1)(2)。 この種類の流量計は, 高感度, 高速応答, 小型, 低消費電 力など MEMS 特有の特長に加え, 熱式の計測原理のため質 量流量を直接計測できることが大きな強みになっている。 ほとんどの流量計が体積流量計測であるのに対し，エネル ギー効率に直接関係する質量流量を計測できることは上述

* 東京理科大学 大学院 工学研究科

干102-0073 東京都千代田区九段北 1-14-6

Tokyo University of Science, Department of Mechanical Engineering

1-14-6 Kudankita, Chiyodaku, Tokyo102-0073

** (株) 山武 マイクロデバイス部

干251-8522 神奈川県藤沢市川名 1-12-2

Yamatake Corporation, Micro Device Department

1-12-2 Kawana, Fujisawa, Kanagawa 251-8522
したような様々な分野に適しており，特に従来の流量計で は実現が困難であった新規用途への応用例が多くなり，流 量最適制御の面などから $\mathrm{CO}_{2}$ 排出量削減にも貢献すると考 えられる。

そこで，今後も期待されるさらに多くの新たなアプリケ ーション開発を実施する際，例えば，事前の可能性評価， 開発・評価方針の設定，回路や流路設計，実施困難な実験 の補間, センサデザインの改良などを効率良く行なうため に，精度の高い実用的なシミュレータの実現が望まれてい る。過去にも数值計算による多くの解析例が報告されてい るが(3) (5), 実際の回路の動作を含めた電気出力が得られる ものではなく，マイクロデバイスの開発初期段階での基礎 研究的なものが多い。一方, SPICE (Simulation Program with Integrated Circuit Emphasis) を用いた電気-熱の連成解析モデ ルによるシミュレーションが提案され, 電気的特性を含め た情報を得られることが報告されている(6)(7)。しかし，これ らもセンサの開発の初期段階に関するものであり，センサ 周りの流体の熱的挙動を詳細に求めるまでには至っていな い。

本稿では 2 素子型の MFS を例題に選び, SPICE をベース とした市販の電気回路シミュレータ内に, MFS, 制御回路, 
流体についての電気-熱の連成解析モデルを構築し，実験デ ータと比較してその実用性を確認したので報告する。

\section{2. 電気-熱等価回路モデル}

\section{〈2·1〉 2 素子型 MFS}

(1) 構 造 図 1 に本研究で使用した 2 素子型MFS のセンサチップ上面の拡大写真を示す。チップサイズは, 1 辺が $1.7 \mathrm{~mm}$, 厚さ $0.5 \mathrm{~mm}$ である。シリコン基台中央の深さ 約 $200 \mu \mathrm{m}$ のキャビティ（空洞）上には，窒化シリコンでで きた厚さ約 $1 \mu \mathrm{m}$ のダイアフラムが作られており, その中央 のスリットの両側にそれぞれヒータ兼温度センサが対称に 配置され, シリコン基台外周上には周囲温度センサが形成 されている。ヒータ兼温度センサおよび周囲温度センサは 白金薄膜であり，その抵抗值から温度を測定できる。キャ ビティはシリコンの異方性エッチング技術により形成され ており, ダイアフラムの多数のスリットは, エッチング液 を導入するためと, 熱絶縁のために設けられている。

（2）動作方式２素子型 MFS の動作方式としては, 一 般的に以下の 2 種類が知られている。その 1 つは, それぞ れのヒータ兼温度センサを別々に, 周囲温度センサで測定 された周囲温度より一定温度高く制御し, そのとき必要な 電力の差を出力とするタイプである。流れが無いとき各電 力はほぼ同じになるが, 流れに応じて上流側のヒータ兼温 度センサの電力が下流側よりも大きくなる。他方は, 図 2 に示すように 2 つヒータ兼温度センサを電気的に接続し, 1 つのヒータ兼温度センサとして周囲温度センサで測定さ れた周囲温度よりある一定温度高く制御し, そのときの上 流側・下流側ヒータ兼温度センサの電圧差（ $\propto$ 温度差 $\propto$ 抵

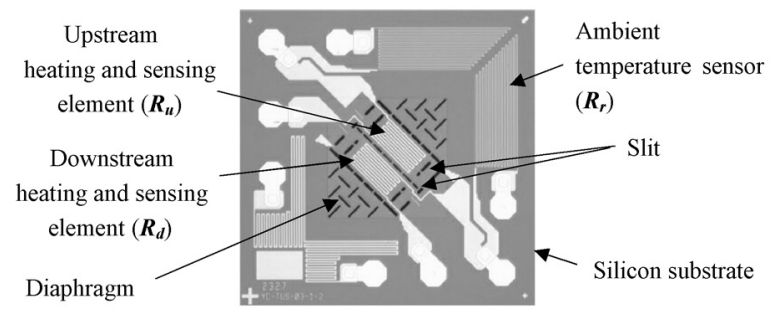

図 12 素子型マイクロフローセンサ

Fig. 1. Top view of the two-element MFS

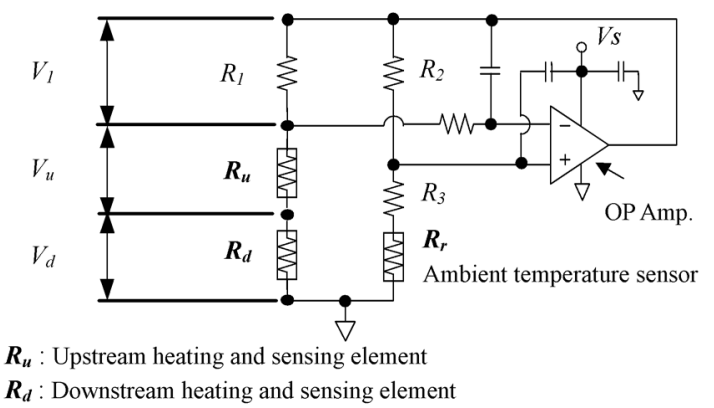

図 22 素子型 MFS $の$ 制御回路

Fig. 2. Control circuit of the two-element MFS
抗值差）を出力とするタイプである。本稿では, 後者の動 作方式について検討した。センサ出力 $V_{\text {out }}$ は, (1)式で表さ れる。

$$
V_{\text {out }}=V_{d}-\frac{\left(V_{u}+V_{d}\right)}{2}
$$

〈2·2〉熱等価回路モデル（MFS と流体）電気と熱 の間には表 1 に示すアナロジーが知られており, 従来から 種々の解析に利用されている。また, 熱等価回路のモデル 化では系をいくつかの要素に分け, その要素の中心にノー ドを配置し，ノード間を熱抵抗で接続した抵抗ネットワー クモデルと，ノードに要素全体の熱容量を持たせる集中熱 容量法が使用され，本研究でもこれらの手法を採用した。

モデル化する領域は, 図 3 に示すようなヒータ兼温度セン サとその上流下流側の部分のみに限定し, その $Z$ 方向外側 の部分は除外した。また, ダイアフラムの上流下流端部は 矩形に簡略化している。なお, $X, Y, Z$ はそれぞれ, 流体 の流れ方向, 流路の高さ方向, スパン方向と定義する。セ グメントの $Z$ 方向は図 4 に示すように分割せず, ヒータ兼 温度センサの長さ $280 \mu \mathrm{m}$ に合わせ, モデル化領域内の $Z$ 方 向温度分布は平均化して取り扱った。 $X$ 方向については, ヒ 一タ兼温度センサ部分は抵抗パターン 2 本分を 1 組として

表 1 電気と熱のアナロジー

Table 1. Analogies between electrical and thermal parameter

\begin{tabular}{|l|l|}
\hline \multicolumn{1}{|c|}{ Electrical parameter } & \multicolumn{1}{c|}{ Thermal parameter } \\
\hline Voltage $(\mathrm{V})$ & Temperature difference $(\mathrm{K})$ \\
\hline Current $(\mathrm{A})$ & Heat flow $(\mathrm{W})$ \\
\hline Resistance $(\Omega)$ & Thermal resistance $(\mathrm{K} / \mathrm{W})$ \\
\hline Capacitance $(\mathrm{F})$ & Thermal capacitance $(\mathrm{J} / \mathrm{K})$ \\
\hline
\end{tabular}

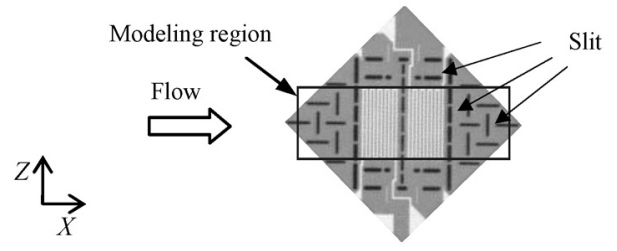

図 3 ダイアフラムのモデル化領域

Fig. 3. Modeling region of the diaphragm

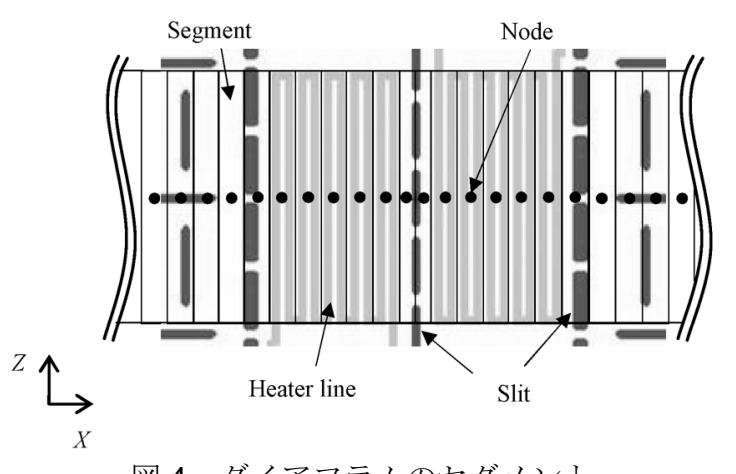

図 4 ダイアフラムのセグメント

Fig. 4. Segments on diaphragm 
約 $30 \mu \mathrm{m}$ ずつ 5 つのセグメントに分割し，その他の部分も それとほぼ同じサイズでできるだけ均等になるように分割 した。また, 流体部分も図 5 に示すように $X-Z$ 方向はダイ アフラムのセグメントサイズに合わせ, $Y$ 方向はダイアフラ ム近傍では細かくなるように分割した。セグメント中央に はノードを配置して，各ノードは(2)式で表される熱抵抗 $R_{t}$ で接続し, ( 3 )式で表される各セグメントの熱容量 $C_{t}$ をま とめてノードに与えた。ダイアフラムの熱抵抗は, その部 分の構成材質の熱抵抗を構造に合わせて直列・並列に合成 して求めた。熱容量も同様にその部分の材質の熱容量を合 成した。なお, ダイアフラムの厚さは約 $1 \mu \mathrm{m}$ であり, 厚さ 方向（ $Y$ 方向）の温度勾配は無視でき, 一定温度とみなせる ため, 厚さ方向熱抵抗は省略した。ダイアフラムの $Z$ 方向 への熱伝導の影響は大きいため, ダイアフラムの各ノード と室温になると予想される $Z$ 方向にあるスリットの位置と 熱抵抗で接続した。流体部分の $Z$ 方向への熱伝導の影響は 小さく無視できると考えられるため，熱抵抗を設けず断熱 とした。

$$
R_{t}=\frac{\left(T_{2}-T_{1}\right)}{Q_{\text {cond }}}=\frac{L}{\lambda \cdot S}
$$

$C_{t}=\rho \cdot C_{p} \cdot V_{m}$

ここで， $T_{2}$ はノード $n_{2}$ における温度， $T_{1}$ はノード $n_{2}$ の上流側のノード $n_{1}$ における温度, $Q_{\text {cond }}$ は $n_{1}-n_{2}$ 間の熱伝導による熱流, $L$ は $n_{1}-n_{2}$ 間の距離, $\lambda$ は熱 伝導率， $S$ はセグメントの $n_{1}-n_{2}$ 方向に垂直な面の 断面積, $\rho$ 密度, $C_{p}$ は定圧比熱, $V_{m}$ はセグメント の体積である。

流体として空気を選択し, 膜温度 (発熱部温度と周囲温 度の平均值）における熱物性值を使用した。また, 窒化シ リコンや白金の薄膜の熱物性值は, 膜厚やプロセス等に依 存することもあり文献から得ることは難しいため, バルク の值を使用した。なお, 窒化シリコンの熱伝導率に関して はバルクでも色々な值になり, さらに薄膜に関しては近年 盛んに研究されているが, バルク值より 1 桁程度小さいこ とが報告されている(8) (10)。窒化シリコンの熱伝導率は，シ ミュレーション結果への影響が大きい最も重要なパラメー

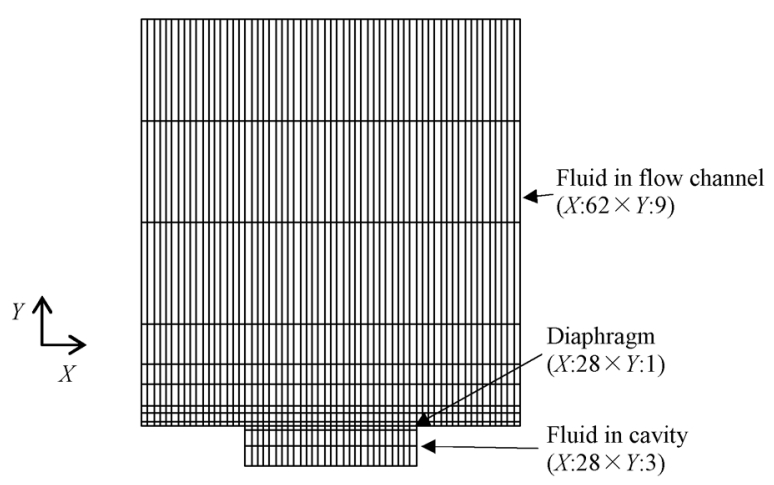

図 $5 X-Y$ 面のセグメント

Fig. 5. Segments on $X, Y$-direction
タであると考えられるため, 流れの速度が零の時に計算結 果が実験結果と一致するように決定した。

流体中の伝熱は，以下のように定義した。まず，ヒータ 兼温度センサの温度は, 通常の使用状態では $150^{\circ} \mathrm{C}$ 程度以下 なので, 熱放射は無視できる。また, MFS の寸法は非常に 小さくグラスホフ数 $G r$ とプラントル数 $P r$ の積であるレイ リ一数 $R a （=G r \cdot P r)$ は 0.2 程度であり, 自然対流が発生す る目安である 1700 よりも 4 桁も小さいため, 自然対流は無 視できる。さらに, キャビティ内に流れが入り込まないよ うにダイアフラムのスリットを細くしてあるため, キャビ ティ内の流れは無視できる(11)。よって, 流体中の伝熱は, 流路内流体部分では熱伝導と強制対流熱伝達, キャビティ 内流体部分では熱伝導のみになる。2 次元平行平板間の層流 (2 次元ポワズイユ流れ) において, $X$ 方向は熱伝導と強制 対流熱伝達, $Y$ 方向は熱伝導のみ, ダイアフラム表面と流体 間の伝熱は熱伝導, 各ノードにおける流速は(5)式(12)で与え られる。前述した仮定のもとで, 強制対流熱伝達 $Q_{\text {conv }}$ は各 ノードにおけるエネルギー収支から(4)式で表される。

$$
\begin{aligned}
& Q_{\text {conv. }}=U \cdot S_{Y Z} \cdot \rho \cdot C_{p} \cdot\left(T_{2}-T_{1}\right) \\
& \text { ここで，Uはノードにおける流速， } S_{Y Z} \text { はセグメン } \\
& \text { トの } Y-Z \text { 面の断面積である。 }
\end{aligned}
$$

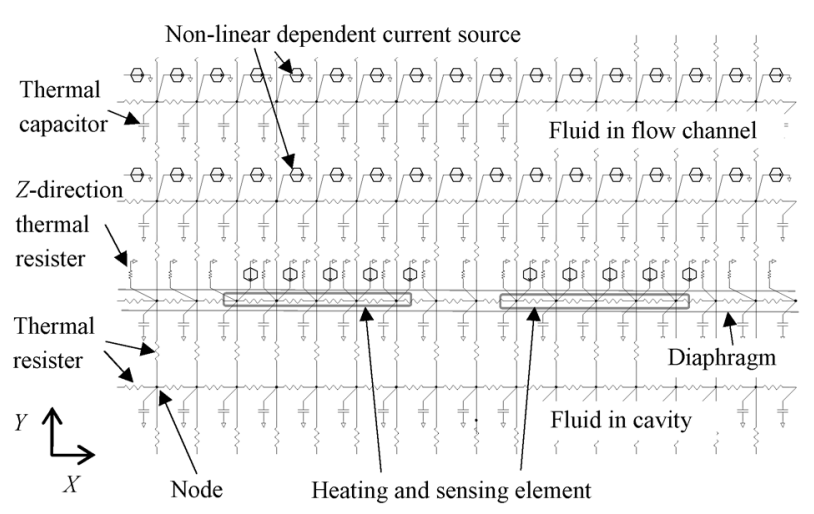

図 6 シミュレータに作成した熱等価回路の一部

Fig. 6. Part of equivalent thermal circuit on Simulator

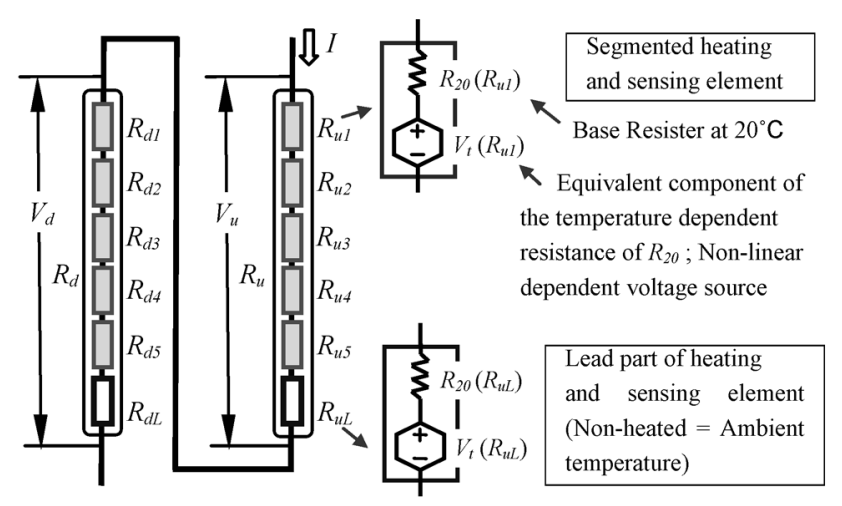

図 7 ヒータ兼温度センサの電気回路モデル

Fig. 7. Heating and sensing element model for electrical circuit 


$$
U=6 \cdot U_{m} \cdot\left(\frac{y}{h}-\left(\frac{y}{h}\right)^{2}\right) \cdot \frac{1}{C_{z}}
$$

ここで, $U_{m}$ は流路断面の平均流速， $y$ はダイアフ ラムからの $Y$ 方向距離, $h$ は流路高さ, $C_{z}$ は流路の 2 次元性からのずれを補正するための係数であり，

(6)式で表せる ${ }^{(13)}$ 。

$$
C_{z}=\left[1-\frac{192 \cdot h}{\pi^{5} \cdot z} \sum_{n=1,3, \ldots}^{\infty} \frac{1}{n^{5}} \tanh \left(\frac{n \cdot \pi \cdot z}{2 \cdot h}\right)\right]
$$

ここで, $h$ は流路高さ， $z$ は流路の幅である。

図 6 にシミュレータの編集画面上で作成した熱等価回路の 一部を示す。強制対流熱伝達は，(4)式を代入した非線形従 属電流源で表される。また，分割されたヒータ兼温度セン サの発熱も，発生する電力の式を代入した非線形従属電流 源で表される。

〈2·3〉電気回路モデル（制御回路）電気回路は, 実験で使用した図 2 の制御回路をそのままシミュレータに 移植し，それぞれ 5 つに分割されたヒータ兼温度センサ $R_{u 1}$ $\sim R_{u 5}, R_{d 1} \sim R_{d 5}$ とそのリード部分 $R_{u L}, R_{u L}$ (非発熱部, 熱等価 回路ではモデル領域外）は，図 7 に示すようにベース抵抗 $R_{20}$ と非線形従属電圧源 $V_{t}$ からなる等価回路で表した。ベー 不抵抗 $R_{20}$ は分割された各抵抗の $20^{\circ} \mathrm{C}$ における抵抗值, $V_{t}$ は $R_{20}$ の温度依存抵抗分を表す等価電圧であり $(7)$ 式が代入 された非線形従属電圧源で表される。なお，周囲温度セン サ $R r$ も同様に $R_{20}$ と $V_{t}$ で表されている。

$$
V_{t}=R_{20} \cdot\left(\alpha \cdot(T-20)+\beta \cdot(T-20)^{2}\right) \cdot I
$$

ここで， $\alpha ， \beta$ はそれぞれ 1 次および 2 次抵抗温度 係数, $T$ はノードの温度, $I$ は $R_{20}$ に流れる電流で ある。

\section{3. 実験装置}

2 素子型 MFS の測定は, 図 8 に示す長さ $200 \mathrm{~mm}$, 幅 $30 \mathrm{~mm}$, 高さ $2 \mathrm{~mm}$ のマイクロセンシング風洞で行われた。流路幅と 高さの比は $15\left(C_{z}=0.96\right)$ であり, 2 次元平行平板間の十分

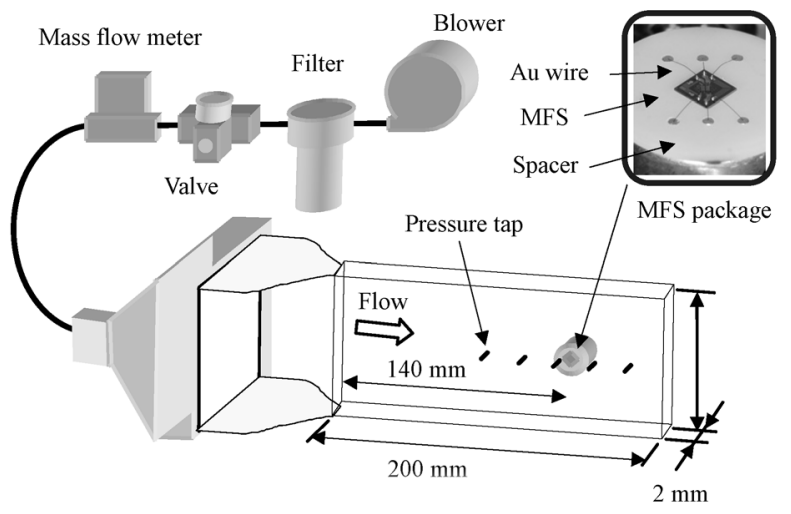

図 8 実験用小型風洞

Fig. 8. Schematic view of wind tunnel
発達した層流（2 次元ポワズイユ流れ）が得られている。ま た，MFS チップの上面が，流路壁面と同じ位置に段差無く 取り付けられるようにした。

\section{4. 結果と考察}

上述したモデルによる計算および実験は，周囲温度 $25^{\circ} \mathrm{C}$ で，ヒータ兼温度センサの平均温度が周囲温度より $60^{\circ} \mathrm{C}$ 高 くなるように制御した状態で実施した。まず，流れがない 状態におけるヒータ兼温度センサの電力の計算值が実験值 と一致するように，ダイアフラムの材質である窒化シリコ ンの熱伝導率を $4.1 \mathrm{~W} / \mathrm{m} \cdot \mathrm{K}$ に決定した。

図 9 には, 流路断面積で平均した流速（以下平均流速と 表現する）に対する上流下流のヒータ兼温度センサの合計 電力についての計算值と実験值の比較を示す。困 10 には, 平均流速に対する上流下流のヒータ兼温度センサの電圧に ついての計算值と実験值の比較を示す。図 11 には，平均流 速に対するセンサ出力電圧 $V_{\text {out }}$ の計算值と実験值の比較を 示す。図 12 には, 平均流速に対する上流下流のヒータ兼温 度センサの, 抵抗值から算出された平均温度の変化につい ての計算值と実験值の比較を示す。図 13 には, 平均流速に 対するダイアフラムの $X$ 方向温度分布の変化についての計 算值を示す。図 14 は図 13 において, ダイアフラム中央部 の上流下流ヒータ兼温度センサ部分を拡大したものを示 す。図 15 には, 平均流速 $0,0.5,5 \mathrm{~m} / \mathrm{s}$ における流体の温度

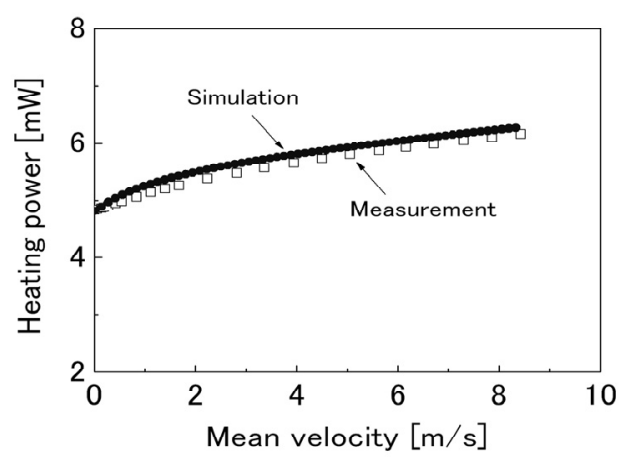

図 $9 R_{u}, R_{d}$ 合計電力の流速特性

Fig. 9. Characteristics of total heating power on $R_{u}$ and $R_{d}$

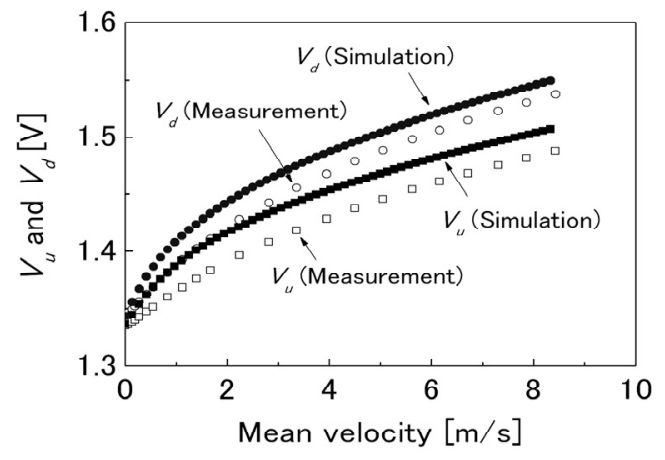

図 $10 V_{u}, V_{d}$ の流速特性

Fig. 10. Characteristics of $V_{u}$ and $V_{d}$ 


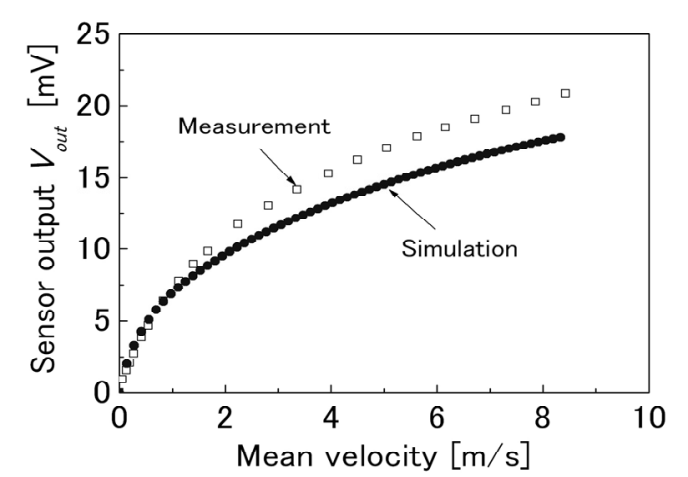

図 11 センサ出力 $V_{\text {out }}$ の流速特性

Fig. 11. Characteristics of sensor output $\left(V_{\text {out }}\right)$

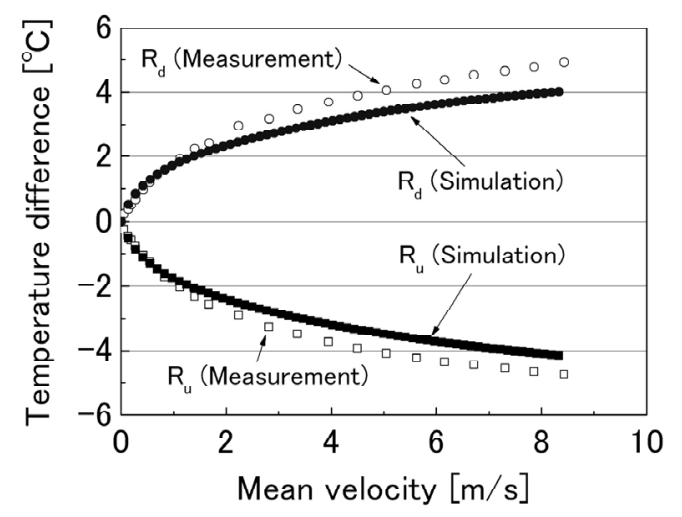

図 12 流速に対する $R_{u}, R_{d}$ 平均温度変化

Fig. 12. Temperature variation of $R_{u}$ and $R_{d}$ vs. Mean velocity

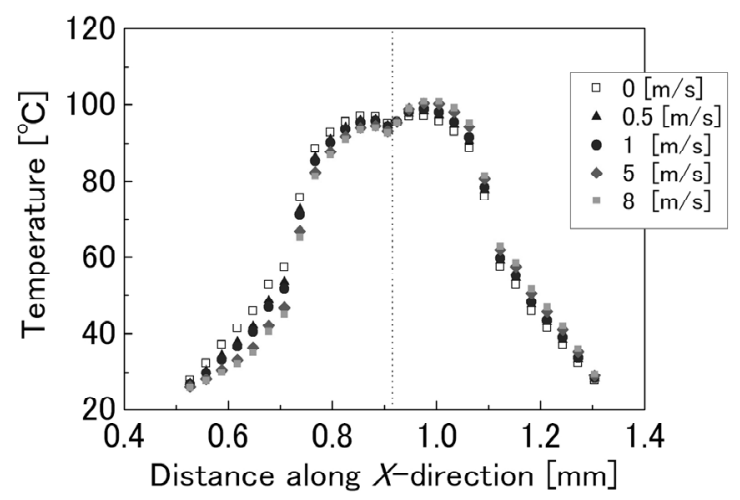

図 13 流速に対するダイアフラム $X$ 方向の温度分布変化 Fig. 13. Temperature distribution of diaphragm vs. Mean velocity

分布についての計算值を示す。なお, 図 9〜図 15 のグラフ データの計算時間は, Pentium4 (2.53GHz) クラスの PC でい ずれも 1〜2 分程度以下である。

本研究で採用した窒化シリコンの熱伝導率 $4.1 \mathrm{~W} / \mathrm{m} \cdot \mathrm{K}$ と いう数值は，熱物性データベース ${ }^{(10)}$ に収録されている薄膜 のデータ $1 \sim 3 \mathrm{~W} / \mathrm{m} \cdot \mathrm{K}$ と比べて妥当であると考えられ, 大胆 な簡素化を行なったにもかかわらず本モデルの熱抵抗回路

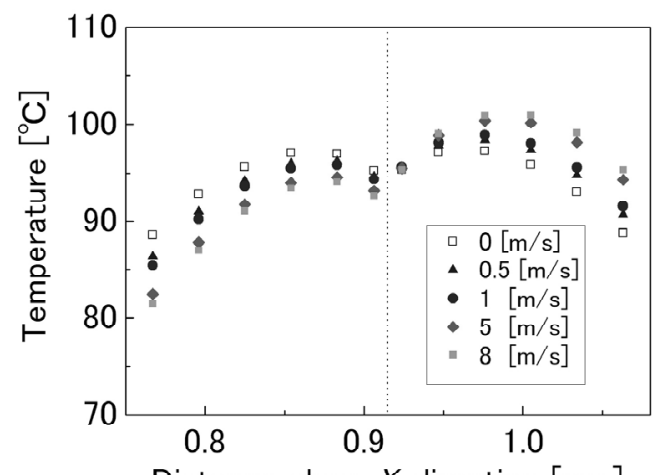

Distance along $X$-direction $[\mathrm{mm}]$

図 14 流速に対する $R_{u}, R_{d}$ 部の温度分布変化

Fig. 14. Temperature distribution of $R_{u}$ and $R_{d}$ area vs. Mean velocity

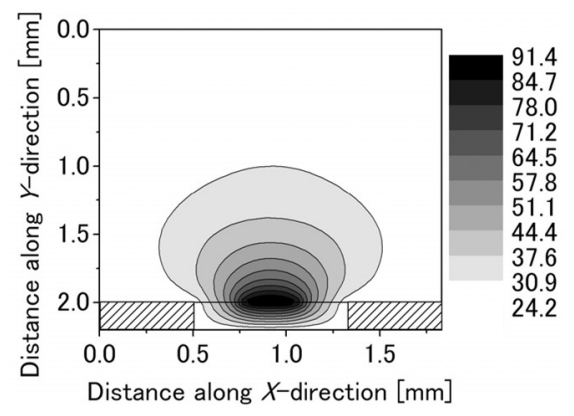

(a) $U_{m}=0[\mathrm{~m} / \mathrm{s}]$

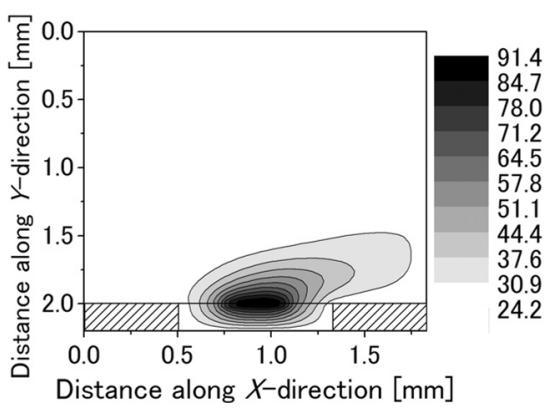

(b) $U_{m}=0.5[\mathrm{~m} / \mathrm{s}]$

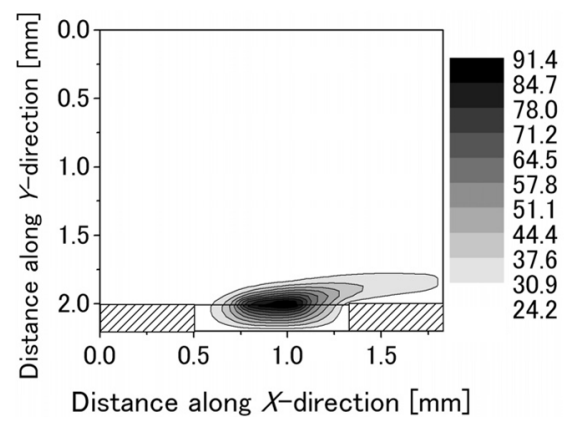

(c) $U_{m}=5.0[\mathrm{~m} / \mathrm{s}]$

図 152 素子型 MFS 周りの温度分布

Fig. 15. Temperature distribution around the two-element

がほぼ適切に構成されていることが分かる。ただし，上記 熱物性データベース ${ }^{(10)}$ に収録されている窒化シリコン薄膜 の熱伝導率は, 膜厚方向の測定值であるため, 更なる調査 
が必要である。

図 9〜図 12 の結果でも, 計算值と実験值の傾向がほぼ一 致しており, 充分実用レベルに達していると思われるが, 計算值の方が低流速での出力が高く, 高流速で低くなって いる点は今後検討すべき課題である。MFS 周りのわずか数 百 $\mu \mathrm{m}$ の範囲の気体中では約 $70^{\circ} \mathrm{C}$ 以上の温度差が存在し， 空気の熱伝導率 $\lambda$, 密度 $\rho$, 粘性係数 $\mu$ はそれぞれ $20 \%$ 程度 変化する。 $\lambda, \rho$ の温度依存性によるセンサ出力への影響につ いては無視できることを確認済みであるが，壁面流速勾配 への影響が考えられる $\rho, \mu$ の温度依存性については, 特に 低流速時に高温部で壁面流速勾配が緩やかになりセンサ出 力の低下が予想されるため, 今後の調査が必要である。

図 13 で $X$ 軸の $0.7 \mathrm{~mm}$ と $1.1 \mathrm{~mm}$ 付近で温度が急激に下が っているのは, ダイアフラムのそれらの位置にスリット, つまり, 空気層があるためであり, この断熱構造が有効に 機能していることが分かる。

\section{5. まとめ}

2 素子型 MFS の制御回路, 流体を含めた電気・熱の連成 解析モデルを電気回路シミュレータ内に構築して計算值と 実験值の比較を行なった結果，その傾向に非常に良い一致 が得られた。また, 電気的な特性やセンサ周りの流体温度 などに関する詳細な情報を得られることも確認できた。こ のモデル化およびシミュレーション手法は，3 素子型 MFS や他の MEMS デバイスの解析へも応用可能であり, 動特性 や他の流体についての解析も可能である。今後, このツー ルにより MFSやその他のMEMSデバイスに関する研究開発 をさらに効率良く進めることが可能と思われる。

(平成 19 年 4 月 25 日受付, 平成 19 年 9 月 3 日再受付)

\section{文献}

（1）上運天昭司：「マイクロフローセンサとその応用」, 計測と制御, Vol.42, No.12, pp.998-1004 (2003)

(2) K. Otakane, K. Sakai, and M. Seto : "Development of the Thermal Flow Meter", SICE Annual conference, Fukui, pp.2031-2034 (2003)

( 3 ) F. Mayer, G. Salis, J. Funk, O. Paul, and H. Baltes : "Scaling of Thermal CMOS Gas Flow Microsensors", Proc. IEEE MEMS, pp.126-131 (1996)

(4) T. Yoshino, Y. Suzuki, N. Kasagi, and S. Kamiunten : "Optimum Design of Micro Thermal Flow Sensor and Its Evaluation in Wall Shear Stress Measurement", Proc. IEEE MEMS, Kyoto, pp.193-196 (2003)

(5) M. Yoshida, K. Toda, M. Yamamoto, S. Kamiunten, and S. Honami : "Numerical Study on Thermal and Fluid Flow Around the New Type of Micro Flow Sensor", FEDSM2003-45068, Proc. ASME-JSME Fluids Engineering Division Summer Meeting, Honolulu (2003)

(6) F. J. Auerbach, G. Meiendres, R. Muller, and G. J. E. Scheller : "Simulation of the thermal behavior of thermal flow sensors by equivalent electrical circuits", Sensors and Actuators A, Vol.41-42, No.1, pp.275-278 (1994)

(7) N. R. Swart and A. Nathan : "Coupled Electrothermal Modeling of Microheaters Using SPICE”, IEEE Trans. Electron Devices, Vol.41 No.6, pp.920-925 (1994)

(8) S. -M. Lee and D. G. Cahill : "Heat transport in thin dielectric films", J. Appl. Phys., Vol.81, No.6, pp.2590-2595 (1997)

(9) B. L. Zink, B. Revaz, J. J. Cherry, and F. Hellman : "Measurement of thermal conductivity of thin films with a Si-N membrane-based microcalorimeter", Rev. Sci. Instrum., Vol.76, 024901 (2005)

(10) The database on NMIJ (National Metrology Institute of Japan) website: http://www.nmij.jp/kosei/database en.html

(11) H. Nakajima, K. Inoue, Y. Nakashima, S. Kamiunten, M. Yamamoto, and S. Honami : "Behavior of Thermal and Fluid Flow around a Micro-Sensor", Trans. JSME, pp.589 -594 (2001-3) (in Japanese) 中嶋秀成 $\cdot$ 井上厚助 $\cdot$ 中島祐介 - 上運天昭司 $\cdot$ 山本 誠 - 本阿弥眞 治: 「マイクロセンサ周りの熱と流れの挙動」, 日本機械学会論文集 (B 編), 67, 655, pp.589-594 (2001-3)

(12) 須藤浩三・長谷川富市・白樫正高 :「流体の力学」, p.81, コロナ社 (2001)

(13) JSME Mechanical Engineers' Handbook, A. Fundamentals, A5 Fluid Mechanics, p.76 (in Japanese)

日本機械学会編 機械工学便覧 基礎編 A5 流体工学, p.76
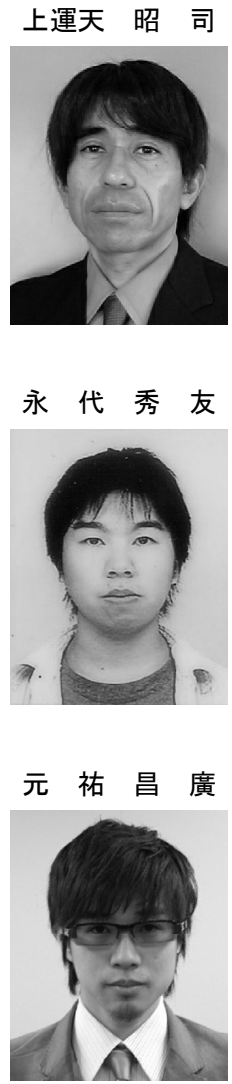

(非会員) 2001 年 3 月慶應義塾大学理工学部シ ステムデザイン工学科卒業。 2006 年 3 月同大学 大学院理工学研究科総合デザイン工学専攻修 了。博士 (工学)。同年 4 月東京理科大学工学 部助手, 2007 年 4 月より助教。マイクロ熱流体 工学, 主に光センシング技術開発に従事。日本 機械学会, 日本熱物性学会員。

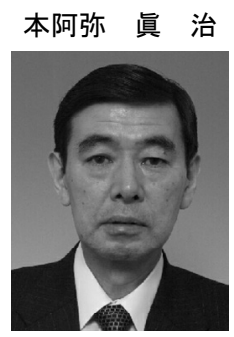

(非会員) 1967 年 3 月慶應義塾大学工学部機械 工学科卒業, 同大学院工学研究科修士課程, 博 士課程を経て, 1974 年 4 月東京理科大学工学部 専任講師, 1987 年 4 月教授.ガスタービンエン ジン要素ならびにマイクロ熱流体工学の研究 に従事。工学博士。日本機械学会フェロー, 米 国機械学会, 米国航空宇宙学会会員。 